\begin{tabular}{c} 
Volume and Issues Obtainable at Center for Sustainability Research and Consultancy \\
Journal of Business and Social Review in Emerging Economies \\
ISSN: 2519-089X (E): 2519-0326 \\
Volume 6: No. 3, September 2020 \\
JSRᄃ \\
Journal homepage: www.publishing.globalcsrc.org/jbsee \\
\hline
\end{tabular}

\title{
How do Energy Consumption, Environmental Degradation and Macroeconomic Performance Cause in Selected Developing Countries? An Analysis?
}

\author{
${ }^{1}$ Noreen Safdar \\ ${ }^{1}$ Assistant Professor, Department of Economics, The Women University Multan, Pakistan, \\ noreen.safdar@wum.edu.pk
}

ARTICLE DETAILS
History
Revised format: August 2020
Available Online: September
2020

\section{Keywords}

Energy environmental

GDP, cointegration.

\section{JEL Classification}

MO, M14 consumption, degradation, employment,

\begin{abstract}
The objective of study is to see the long run association between energy use, environmental degradation and macroeconomic performance in selected developing countries. For this purpose, fifty developing countries are selected from 1990 to 2016. GDP and employment are taken as proxy variables of macroeconomic performance while energy use, environmental degradation, labor force, gross capital formation, manufacturing value added, personal remittances received are GDP deflators are other variables. Homogenous panel causality testing is used for explanation of causal and effect linkage of energy consumption, environmental degradation and macroeconomic variables in all selected developing countries after the cross sectional dependence test and pedroni test for panel cointegration. The results reveal that there is cross sectional dependency amongst all variables in selected developing countries. It specifies that the instability in one country will be spread to other country which reflects the effectiveness of developing countries collaborative development strategy. Pedroni test for Co-integration and kao test identifies the long run association between economic energy use, environmental degradation and macroeconomic performance in selected developing countries.
\end{abstract}

(C) 2020 Center for Sustainability Research and Consultancy Pakistan under a Creative Commons Attribution-NonCommercial-ShareAlike 4.0

\begin{abstract}
Corresponding author's email address: noreen.safdar@wum.edu.pk
Recommended citation: Safdar, N. (2020). How do Energy Consumption, Environmental Degradation and Macroeconomic Performance cause in Selected Developing Countries? An analysis? Journal of Business and Social Review in Emerging Economies, 6(3), 1189-1197
\end{abstract}

\section{Introduction}

Energy consumption, environmental degradation and macroeconomic performance are interlinked. As macroeconomic performance can be enhanced by energy consumption where environment is badly affected by energy in the form of water and air pollution. Human health and quality of life is also threatened by environmental degradation. Environmental problems can cause harmful effects on biophysical environment. The environmental impact of energy is diverse as energy generation and consumption both has huge impact on the environment.

Air pollution is mainly produced by burning of fossil fuels, coal, oil and natural gas. Carbon dioxide emission is an indicator to measure how pollutants are emitted from burning of fossil fuels. Burning of fossil fuels also leads to other climate changes such as global warming and depletions of ozone layer. Other environmental issues linked with energy use are greenhouse effect due to $\mathrm{CO}_{2}$ emissions, acid rains due to $\mathrm{SO}_{2}$ and $\mathrm{NO}_{2}$ emission and health risk for people 
living near the nuclear power stations especially in developing countries

Apart from energy sector, technological advancement and industrialization, transportation, use of pesticides in agriculture sector, over population, urban sprawling, and deforestation and over production have serious effects on environment. The environmental impact of energy had been a topic of debate during the last two decades. The interrelatedness between energy and environment is diverse and is continuously evolving.

The use of energy from non-renewable sources can result in shortage of energy resources in future especially in developing countries. The solution of environmental problems requires a reduction in the energy use in production and consumption activities. Energy conservation is a control measure to use fewer amounts of energy consumption in production and consumption which leads to safe environmental methods of production and consumption. Energy efficiency is an efficient use of energy by adopting the technological innovations which ensure reduction in energy utilization per unit of output.

The environmental impact of energy can be controlled by energy conservation and energy efficiency. It will also reduce the energy costs by proper utilization of energy sources and will also reduce the energy imports from foreign countries. It will help to control pollutants emissions and will improve environmental quality. In this context, energy intensity must be reduced and energy efficiency must be increased.

According to World Bank report, in 1990 real GDP per capita in low income, lower middle income and upper middle income were 460.47, 964.84, 3197.79 US Dollars groups while in 2016 it was 579.06, 1965.71,7575.90 US Dollars correspondingly. This shows wide range of variation in growth rate in these countries from 1990-2016. In 1990, $\mathrm{CO}_{2}$ emissions were $0.27,0.99,3.46$ metric ton per capita in selected three groups as compared to 0.25,1.47.6.59 metric ton per capita in 2016. This identified that there is minor lessening in $\mathrm{CO}_{2}$ emissions in low income group. Additionally, the corresponding energy use of three income was $371.51,554.76$ and $1373.07 \mathrm{~kg}$ of oil equivalent per capita in 1990 ac compared to the $395.86,647.1,2192.10 \mathrm{~kg}$ of oil equivalent per capita in 2016.

This study is aimed at examining the effects of energy use and environmental degradation on growth for panel data of fifty developing countries. Section I is the introduction, section II gives review of some prior studies on interrelationship of energy use, environment and economic growth, section III provides data and methodological issues, results are interpreted in section IV and conclusion and policy recommendation is explained in section V and lastly references are given.

\section{Literature Review}

This section gives review of some prior studies on interrelationships amongst energy use, $\mathrm{CO} 2$ and growth, various studies have explained the causal relationship among energy use, environmental degradation and growth level. On the contrary, this section reviews the findings of all those studies who elaborated the impact of energy use, environmental degradation, on macroeconomic performance which are as follows,

Jarnel and Derball (2016) considered the influence of energy use and growth on environmental degradation for Asian countries. The panel data was used for analysis from the time period 1991 to 2013. The applied cointegration test, pooled OLS and panel causality was used to estimate the influence of energy use and growth on environmental degradation for Asian countries. The study came to conclusion that there was positive significant association between growth, energy use and environmental degradation.

Mohiuddin et al. (2016) utilized the time series data for years 1971-2013 and studied association between carbon emission, energy use and GDP in Pakistan. The applied vector-error correction model was used to find out linkage. The study concluded that energy production from oil and energy production from coal had negative effect on carbon emission and growth.

The interrelationship of growth, energy use and CO2 emissions were described by Sghari and Hammami in 2016 for Tunisia by taking time series data for years 1971-2004. The results indicated the long run positive link among growth, 
energy and CO2 emissions in Tunisia. In Tunisia, there was limited energy supply as compared to energy demand so study focused on energy conservation policy to meet future need. The study had limitation that it did not discuss the environmental protection policy for Tunisia.

Zhang and Gao (2016) discussed the effects of electricity consumption on environment in China. The study highlighted the function of energy sector in growth and development. The study also concluded that energy consumption was source of environmental pollution in China. It was suggested by study in order to cope with environment issues in China, government should make polices to control energy balance in the country.

The impact of tourism on growth and energy use was described by Zhang and Gao in 2016. By obtaining country's panel data of years 1995-2011, it was explained that tourism was affecting environment adversely in China. Due to tourism there was increase in economic activities and energy use was also increased which caused the environmental pollution. The findings showed that tourism did not support Environmental Kuznet curve in central China but in Eastern and Western China it was supported to some extent. Furthermore, causality results showed two ways causality among growth and $\mathrm{CO} 2$ in most of regions of China.

Aiyetan and Olomola (2017) examined the relationship between energy use, population, environmental degradation, and growth in Nigeria by using ARDL method and granger causality test for the time period 1980 to 2012 . The end result showed that there was no unidirectional causality between carbon emission and energy use whereas unidirectional causality existed between growth and population. In both longrun and shortrun, energy consumption and population growth had positive effect on carbon emissions. Environmental kuznet curve was found to be existed in long run.

The effects of energy use on environmental pollution were explained by Khalid et al. in 2017 for Pakistan over the period of 1980-2008. By using autoregressive distributed lag approach, the long run and short run relation amongst energy use, carbon emissions, GDP, capital formation and FDI was estimated. The results explained that GDP and energy use was positively linked to foreign direct investment while negatively linked to climate and energy consumption led to increase in the environmental pollution in Pakistan in this time span.

The correlation between growth, energy use and environmental degradation was observed by Nasreen et al. in 2017 by utilizing the panel data of year 1980-2012 for South Asian countries. By applying bound test and Granger causality tests, the results showed that quality of environment was depending on the size population, growth level and energy use and results also showed inverted U-shaped relation between growth and quality of environment.

Rehman and Rashid (2017) studied the influence of energy utilization on environmental degradation by using panel data from 1974 to 2010 . For estimation process, the fully modified and dynamic ordinary least-square method was applied. The study confirmed the existence of environmental Kuznet curve. Energy consumption had significant influence on environmental degradation. Population had positive effect on carbon emissions and economic growth also had positive significant influence on carbon emissions. In other words, energy consumption, population and economic growth were contributing to environmental degradation.

The interrelationship among growth, energy utilization and environmental degradation in China was investigated by Sek and Chu in 2017 for years 1970-2012. The variables used in this study were greenhouse gases emission, GDP and energy utilization. The applied granger causality and cointegration testing were econometric technique employed to discover the relationship between variables. The result illustrated that there was bidirectional link between energy utilization and greenhouse gases and unidirectional link existed between gross domestic product and energy utilization in short run. It was observed there existed symmetric link between energy utilization and greenhouse gases in long run. The study did not discuss the about existence of Environmental Kuznet curve.

The linkage among per capita GDP, per capita carbon emission, financial development, per capita total renewable energy and urbanization was explored by Korkut Pata in 2018. The study concluded that growth, urbanization and financial development directed to environmental degradation while total renewable energy use and other alternative 
energy use had no considerable effect on environment. The study highlighted that growth instigated the $\mathrm{CO}_{2} \mathrm{emissions}$ followed by financial development and urbanization.

Adams and Nisiah (2019) found the connection between renewable energy and carbon dioxide emissions by taking the data of 28 Sub Sahara African nations for years 1980-2014. The results have shown that renewable and nonrenewable energy enlarged carbon dioxide emissions in these nations. Furthermore, the study concluded that growth contributed to environmental degradation whereas urbanization had negative impact on carbon dioxide emissions.

Hdome (2019) highlighted the effect of electricity production by fossils and other renewable sources on $\mathrm{CO}_{2}$ emissions in south America for years 1980-2010. The finding found the cross sessional dependence and cointegration among selected variables. The results have shown that there was link between growth, electricity production and $\mathrm{CO}_{2}$ emissions. The renewable energy consumption has inverse link with $\mathrm{CO}_{2}$ emissions.

Mensah (2019) inspected the cause-and-effect link between growth, fossil fuel, carbon emissions and oil prices by utilizing the data of 22 African dividing into two groups i.e. oil exporters and non-oil exporters over the period 19902015. The results explained that there existed bidirectional causal link between foil energy and growth and unidirectional causal link between carbon emission and growth for both panels. A unidirectional causal from oil prices to economic growth and from fossil fuel use to carbon emissions was also noticed for all panel.

The interrelationship between energy use, growth and $\mathrm{CO}_{2}$ emissions for 68 countries was inspected by Muhammad (2019) for years 2001-2017. By using Generalized method of moments and system generalized method of moments, it was identified that energy use was causing economic growth in all countries except middle east and north African countries due to high emissions of $\mathrm{CO}_{2}$.

Safdar et al. (2019) examined the impact of energy use, environmental degradation on employment in 50 developing countries over the period of 1990 to 2016. By using PMG method, the study came to conclusion that energy use and environmental degradation is great threat to human health and quality of life. The study suggested that these countries should adopt renewable energy sources to meet their energy demand. The dependence on renewable energy sources will enhance growth and other economic opportunities without affecting human health and environment.

Safdar et al. (2020) found the impact of coal energy (a kind of non-renewable energy), renewable energy, Greenhouse gases, industrialization, population growth and environmental degradation and on the health of human beings, with the key emphasis on Tuberculosis incidence in Pakistan for the time span 1986 to 2017. The results reported that with an increase in the usage of coal energy, the incidence of Tuberculosis also increased. In addition, the results also highlighted that by turning to the renewable energy (energy by sun, wind and air) the health could be improved as the renewable energy is environment friendly and it does not generate greenhouse gases and it also does not cause environmental degradation.

\section{Data and Methodological Issues}

This section explains the selection of variables being used to find out the causal and effect relationship of energy consumption, environmental degradation and macroeconomic performance for selected developing countries. variables are chosen on basis of their theoretical and empirical significance. GDP and employment are taken as proxy variables of macroeconomic performance while energy consumption, environmental degradation, labor force, gross capital formation, manufacturing value added, personal remittances received are GDP deflators are other variables.

\subsection{Time Period}

The panel data for years 1990 to 2016 is taken to check the connection among energy consumption, environment and macroeconomic performance for selected developing countries.

\subsection{Data Sources}

This research is found on secondary type of data. For all selected developing countries, balanced panel data has been used in this study. Data of all variables for selected countries has been taken from WDI (World Development Indicator 2016). 


\subsection{Selection of countries}

To find the cause-and-effect relationship among energy use, environmental degradation and macroeconomic performance, fifty developing countries have been selected having same economic and environmental issues on the availability of data.

\section{Results and Discussion}

4.1 Cross sectional dependence

Cross sectional dependence specifies that the instability or fluctuations in one country will be spread to other country easily which is mostly ignored in panel data analysis (Peasron, 2006 ; Destek and Aslan,2017). Consequently, cross sectional dependence test is performed firstly in this study.

Table I: Cross Sectional Dependence Tests Results in All Selected Developing Countries

\begin{tabular}{|l|l|l|l|l|l|l|l|l|l|}
\hline Test & GDP & ENC & ENV & LF & GCF & MNVA & PRMTC & EMPL & GDPD \\
\hline $\begin{array}{l}\text { Breusch } \\
- \text { Pagan } \\
\text { LM }\end{array}$ & $29058.5^{* *}$ & $13879.4^{* *}$ & $20096.3^{* *}$ & $29321.5^{* *}$ & $26555.5^{* *}$ & $24134.8^{* *}$ & $11331.9^{* *}$ & $28573.4^{* *}$ & $28422.2^{* *}$ \\
\hline $\begin{array}{l}\text { Pesran } \\
\text { scaled } \\
\text { LM }\end{array}$ & $561.3^{* * *}$ & $254.6^{* *}$ & $380.2^{* *}$ & $566.6^{* * *}$ & $510.7^{* *}$ & $461.8^{* *}$ & $203.1^{* *}$ & $551.5^{* * *}$ & $548.4^{* * *}$ \\
\hline $\begin{array}{l}\text { Bias } \\
\text { adjuste } \\
\text { d LM }\end{array}$ & $560.3^{* *}$ & $253.6^{* *}$ & $379.2^{* *}$ & $565.6^{* *}$ & $509.7^{* *}$ & $460.8^{* *}$ & $202.1^{* *}$ & $550.5^{* * *}$ & $547.4^{* * *}$ \\
\hline $\begin{array}{l}\text { Pesaran } \\
\text { CD }\end{array}$ & $170.2^{* *}$ & $57.08^{* *}$ & $104.9^{* *}$ & $145.5^{* *}$ & $162.5^{* *}$ & $152.9^{* *}$ & $32.79^{* *}$ & $143.9^{* *}$ & $167.9^{* *}$ \\
\hline
\end{tabular}

\{Notes: $* * *$, and $* * *$ denote the $10 \%, 5 \%$, and $1 \%$ levels of significance, correspondingly

The results expose that there is cross sectional dependence amongst all selected variables in all panels. It specifies that the variation in one country will be spread to other country which reflects the effectiveness of developing countries collaborative development strategy.

\subsection{Panel Co-integration}

The panel co-integration test applied in the study to observe the long run affiliation among variables. This test is useful to explain simultaneously long run and short run relationship as well as fixed effect to be heterogenous across the various panel members. Pedroni test for Co-integration and kao test is used to see the long run connection between economic energy consumption, environmental degradation and macroeconomic performance in selected developing countries, results are in table II given below

Table: II Panel Cointegration Results of all selected developing countries

\begin{tabular}{|l|l|l|}
\hline Statistics & Without Trend & With Trend \\
\hline Panel & $4.04^{* *}$ & $3.37^{* * *}$ \\
V statistic & $(0.00)$ & $(0.00)$ \\
\hline Panel & 2.68 & 3.71 \\
Rho statistic & $(0.99)$ & $(0.99)$ \\
\hline Panel & $-1.87^{* *}$ & $-4.47^{* *}$ \\
PP statistic & $(0.03)$ & $(0.00)$ \\
\hline Panel & $-4.45^{* *}$ & 0.606 \\
ADF statistic & $(0.00)$ & $(0.27)$ \\
\hline Group & 5.23 & $8.05^{*}$ \\
Rho statistic & $(0.99)$ & $(0.06)$ \\
\hline Group & -4.56 & $-.740^{* * *}$ \\
PP statistic & $(0.11)$ & $(0.00)$ \\
\hline Group & $-4.56^{*}$ & -1.211 \\
ADF statistic & $(0.06)$ & $(0.33)$ \\
\hline & \multicolumn{2}{|}{} \\
ADF statistics (p value) & $-9.90^{* *}$ & $(0.00)$ \\
\hline
\end{tabular}


\{Notes: *,**, and $* * *$ denote the $10 \%, 5 \%$, and $1 \%$ levels of significance, correspondingly\}

The table II shows the results of the panel cointegration test. The cointegration results show that four out of the seven null hypotheses of no cointegration have been rejected at the 1\%,5\% and 10\% levels of significance. Therefore, there is evidence of the long run association between energy consumption, environmental degradation and macroeconomic performance in selected developing countries.

\subsection{Homogenous Causality Test}

Homogenous panel causality testing is used for explanation of causal link among energy consumption, environmental degradation and macroeconomic variables in all selected developing countries. The findings of homogenous panel causality test in developing countries are reported in table III.

\section{Table: III Panel Causality Analysis in All Selected Developing Countries}

\begin{tabular}{|c|c|c|c|c|c|c|c|c|c|}
\hline \multicolumn{10}{|c|}{ Panel Causality Results for All Selected Developing Countries } \\
\hline \multirow[t]{2}{*}{ Variables } & GDP & ENC & $\mathbf{0}$ & $\mathbf{L F}$ & GCF & MNVA & PRMTC & EMPL & GDPD \\
\hline & $\begin{array}{l}\text { W-Stat } \\
\text { Zbar- } \\
\text { Stat }\end{array}$ & $\begin{array}{l}\text { W-Stat } \\
\text { Zbar- } \\
\text { Stat }\end{array}$ & $\begin{array}{l}\text { W-Stat } \\
\text { Zbar- } \\
\text { Stat }\end{array}$ & $\begin{array}{l}\text { W-Stat } \\
\text { Zbar- } \\
\text { Stat }\end{array}$ & $\begin{array}{l}\text { W-Stat } \\
\text { Zbar- } \\
\text { Stat }\end{array}$ & $\begin{array}{l}\text { W-Stat } \\
\text { Zbar- } \\
\text { Stat }\end{array}$ & $\begin{array}{l}\text { W-Stat } \\
\text { Zbar-Stat }\end{array}$ & $\begin{array}{l}\text { W-Stat } \\
\text { Zbar- } \\
\text { Stat }\end{array}$ & $\begin{array}{l}\text { W-Stat } \\
\text { Zbar- } \\
\text { Stat }\end{array}$ \\
\hline GDP & - & $\begin{array}{l}6.061^{*} \\
10.926^{*}\end{array}$ & $\begin{array}{l}5.957 * \\
10.63 *\end{array}$ & $\begin{array}{l}6.158^{*} \\
11.203^{*}\end{array}$ & $\begin{array}{l}6.179 * \\
11.263^{*}\end{array}$ & $\begin{array}{l}7.554^{*} \\
15.176^{*}\end{array}$ & $\begin{array}{l}3.47 * \\
3.551 *\end{array}$ & $\begin{array}{l}4.59 * \\
6.739 *\end{array}$ & $\begin{array}{l}4.316^{*} \\
5.959^{*}\end{array}$ \\
\hline Energy & $\begin{array}{l}4.526^{*} \\
6.557^{*}\end{array}$ & - & $\begin{array}{l}5.992 * \\
10.729 *\end{array}$ & $\begin{array}{l}3.155^{*} \\
2.656^{*}\end{array}$ & $\begin{array}{l}4.324^{*} \\
5.983^{*}\end{array}$ & $\begin{array}{l}4.435^{*} \\
6.301^{*}\end{array}$ & $\begin{array}{l}4.688^{*} \\
7.0201 *\end{array}$ & $\begin{array}{l}3.422^{*} \\
3.417^{*}\end{array}$ & $\begin{array}{l}.187^{*} \\
5.594^{*}\end{array}$ \\
\hline Environment & $\begin{array}{l}5.164^{*} \\
8.373^{*}\end{array}$ & $\begin{array}{l}5.734 * \\
9.997 *\end{array}$ & - & $\begin{array}{l}3.026^{*} \\
2.288^{*}\end{array}$ & $\begin{array}{l}5.598 * \\
9.6101 *\end{array}$ & $\begin{array}{l}5.253^{*} \\
8.627^{*}\end{array}$ & $\begin{array}{l}3.316^{*} \\
3.115^{*}\end{array}$ & $\begin{array}{l}3.429^{*} \\
3.436^{*}\end{array}$ & $\begin{array}{l}4.108^{*} \\
5.367^{*}\end{array}$ \\
\hline Labor force & $\begin{array}{l}6.392 * \\
11.867 *\end{array}$ & $\begin{array}{l}7.836^{*} \\
15.977^{*}\end{array}$ & $\begin{array}{l}5.281 * \\
8.707 *\end{array}$ & - & $\begin{array}{l}7.061 * \\
13.643 *\end{array}$ & $\begin{array}{l}5.976^{*} \\
10.683^{*}\end{array}$ & $\begin{array}{l}3.523^{*} \\
3.702 *\end{array}$ & $\begin{array}{l}10.431^{*} \\
23.365^{*}\end{array}$ & $\begin{array}{l}5.743^{*} \\
10.023^{*}\end{array}$ \\
\hline Capital & $\begin{array}{l}4.593^{*} \\
6.748^{*}\end{array}$ & $\begin{array}{l}4.401 * \\
6.201 *\end{array}$ & $\begin{array}{l}5.022 * \\
7.968 *\end{array}$ & $\begin{array}{l}4.531^{*} \\
6.571^{*}\end{array}$ & - & $\begin{array}{l}4.559^{*} \\
6.652^{*}\end{array}$ & $\begin{array}{l}3.984^{*} \\
5.014^{*}\end{array}$ & $\begin{array}{l}.146^{*} \\
5.476^{*}\end{array}$ & $\begin{array}{l}5.017^{*} \\
7.955^{*}\end{array}$ \\
\hline Manufacturing & $\begin{array}{l}7.245^{*} \\
14.296^{*}\end{array}$ & $\begin{array}{l}5.601 * \\
9.614^{*}\end{array}$ & $\begin{array}{l}4.896^{*} \\
7.612 *\end{array}$ & $\begin{array}{l}5.068^{*} \\
8.101^{*}\end{array}$ & $\begin{array}{l}5.889 * \\
10.437 *\end{array}$ & - & $\begin{array}{l}3.534^{*} \\
3.735^{*}\end{array}$ & $\begin{array}{l}4.2101^{*} \\
5.657^{*}\end{array}$ & $\begin{array}{l}4.719^{*} \\
7.107^{*}\end{array}$ \\
\hline Remittance & $\begin{array}{l}4.5106^{*} \\
6.513^{*}\end{array}$ & $\begin{array}{l}4.514 * \\
6.523 *\end{array}$ & $\begin{array}{l}3.898^{*} \\
4.769 *\end{array}$ & $\begin{array}{l}2.863 \\
1.824\end{array}$ & $\begin{array}{l}4.466^{*} \\
6.386^{*}\end{array}$ & $\begin{array}{l}4.5111^{*} \\
6.514^{*}\end{array}$ & - & $\begin{array}{l}2.349 \\
0.361\end{array}$ & $\begin{array}{l}2.857 \\
1.522\end{array}$ \\
\hline Employment & $\begin{array}{l}5.237^{*} \\
8.58^{*}\end{array}$ & $\begin{array}{l}7.095^{*} \\
13.87^{*}\end{array}$ & $\begin{array}{l}5.6698 \\
9.812 *\end{array}$ & $\begin{array}{l}2.561 \\
0.966\end{array}$ & $\begin{array}{l}5.6801 * \\
9.842 *\end{array}$ & $\begin{array}{l}5.117^{*} \\
8.24^{*}\end{array}$ & $\begin{array}{l}3.226^{*} \\
2.859^{*}\end{array}$ & - & $\begin{array}{l}4.881^{*} \\
7.569^{*}\end{array}$ \\
\hline GDPD & $\begin{array}{l}4.374^{*} \\
6.125^{*}\end{array}$ & $\begin{array}{l}5.9782^{*} \\
10.69^{*}\end{array}$ & $\begin{array}{l}4.112 * \\
5.397 *\end{array}$ & $\begin{array}{l}4.863^{*} \\
7.516^{*}\end{array}$ & $\begin{array}{l}3.719 * \\
4.2609 *\end{array}$ & $\begin{array}{l}4.166^{*} \\
5.534^{*}\end{array}$ & $\begin{array}{l}4.085^{*} \\
5.303^{*}\end{array}$ & $\begin{array}{l}4.537^{*} \\
6.588^{*}\end{array}$ & - \\
\hline
\end{tabular}

[Note: *, **, and $* * *$ show the values of coefficients are significant at 10 percent, 5 percent and 1 percent respectively]

The findings of homogenous panel causality test in all selected developing countries (ASDCs) are reported in table III. The bivarite causality among GDP and energy, environmental degradation, total labor force, gross capital formation, manufacturing value added, total labor force GDPD is determined. The two way causal association between energy use and environmental degradation, total labor force, gross capital formation, manufacturing value added, remittances received, employment, GDPD is identified. It is noticed that there exists bidirectional causality among environmental degradation and total labor force, gross capital formation, manufacturing value added, remittances received, employment, GDPD. The bidirectional causal relation between total labor force and gross 
capital formation, manufacturing value added, GDPD is found while at same time unidirectional causal relation between total labor force and remittances received, employment is observed. The two ways causal effects among capital formation and manufacturing value added, remittances received, employment, GDPD are observed. Additionally, there also exists bidirectional causality between manufacturing value added and remittances received, employment, GDPD. The bidirectional causality between GDPD and employment also exists. The unidirectional causality running from employment and GDPD towards remittances received is identified.

The feedback hypothesis 'the casual relationships exist between energy, environmental degradation and macroeconomic variables" is also fulfilled in all selected developing countries (ASDCs) and has been found largely by many empirical findings. The various studies concluded the existence of bidirectional causality between growth, CO2 and energy consumption (Govindarajr and Tang, 2012; Sabori and Suliman, 2013; Omri et al., 2015;Abid, 2015; Jammazi, 2015; Wang et al., 2015; Salahuddin et al., 2015; Nasreen et al., 2016; Zang and Gao, 2016 ).

\section{Conclusion and Policy Implication}

The principle aim of given research is to observe the long run relationship and causal link of energy consumption, environmental degradation and macroeconomic performance in selected developing countries. For this purpose, fifty developing countries are selected the secondary source of data for years 1990 to 2016 taken from World Development Indicators is used in this study.

Finally, the study has summarized the whole findings regarding the long run association of energy consumption, environment degradation and macroeconomic performance in all selected developing countries. The results of Pedroni test for Co-integration and kao test shows long run relationship between economic energy consumption, environmental degradation and macroeconomic performance in selected developing countries.

The secondary objective of study is to fulfill the hypothesis, "the casual relationships exist between energy, environment, growth and other macroeconomic variables'. It is elaborated by results that GDP, energy, environmental degradation and all macroeconomic variables are causing each other. (Govindarajr and Tang, 2012; Sabori and Suliman, 2013; Omri, et al., 2015; Abid, 2015; Jammazi, 2015; Jammazi, 2015; Nasreen, et al., 2016; Zang and Gao, 2016 ). On the whole, the feedback hypothesis of study "the casual relationships exist between energy, environmental degradation, economic growth and macroeconomic variables" is also fulfilled in all selected developing countries .

The cross-sectional dependency exists for all variables in developing countries. It means that collaborative development strategy is powerful for all developing countries. Therefore, all Governments of these developing countries should strengthen a unified renewable energy management system to advocate regional cooperation.

The nexus of energy use, environmental degradation and macroeconomic performances exits in developing countries which suggests that energy use is vital for growth, but the fast pace of the $\mathrm{CO} 2$ emissions needs the implementation of substitute sources to energy and tactics to development in order to protect the environment.

The main suggestion by the study is that policy makers should invest in cleaner and environmentally friendly resources of energy to tackle the problem of environmental degradation due to excessive use of energy. 


\section{References}

Abid, M. (2015). The Close Relationship between Informal Economic Growth and 624 Pakistan Journal of Social Sciences Vol. 39, No. 2 Carbon Emissions in Tunisia since 1980: The irrelevance of structural breaks. Sustainable Cities and Society, 15, 11-21.

Adams, S., \& Nsiah, C. (2019). Reducing carbon dioxide emissions; Does renewable energy matter? Science of The Total Environment, 693, 133288.

Adugna, T. (2014). Impacts of manufacturing sector on economic growth in Ethiopia. Journal of Business Economics and Management Sciences 1(1), 1-8.

Ahmad, H. M. \& Ahmad, M. Q. (2002). Foreign Capital Inflows and Domestic Savings in Pakistan: Co integration Techniques and Error Correction Modeling. The Pakistan Development Review 41(4), 825-836.

Ahmad, M.H., Azhar, U., Wasti, S.A., Inam, Z., \& Ghani, N. (2005). Interaction between Population and Environmental Degradation. The Pakistan Development Review, 44(4), 1135- 1150.

Aiyetan, I. R., \& Olomola, P. A. (2017). Environmental degradation, energy consumption, population growth and economic growth: Does Environmental Kuznets curve matter for Nigeria? Economic and Policy Review, $16(2)$.

Alams, S., Fatima, A., \& Butt, M.S. (2007). Sustainable Development in Pakistan in the Context of Energy Consumption Demand and Environmental Degradation. Journal of Asian Economics, 18, 825-837.

Aqeel, A. \& Butt, M.S (2001). "The Relationship Between Energy Consumption and Economic Growth in Pakistan." Asia-Pacific Development Journal, Vol. 8(2), 101-110.

Asafu-adjaye, J. (2000). The Relationship Between Energy Consumption, Energy Prices and Economic Growth: Time series Evidence from Asian Developing Countries. Energy Economics, Vol. 22, 615-625.

Azam, M., Alam, M. M., \& Hafeez, M. H. (2018). Effect of tourism on environmental pollution: Further evidence from Malaysia, Singapore and Thailand. Journal of cleaner production, 190, 330-338.

Bastola, U., \& Sapkota, P. (2015). Relationships among energy consumption, pollution emission, and economic growth in Nepal. Energy Economics, 80, 254-262.

Chen, Y., Zhao, J., Lai, Z., Wang, Z., \& Xia, H. (2019). Exploring the effects of economic growth, and renewable and non-renewable energy consumption on China's $\mathrm{CO} 2$ emissions: Evidence from a regional panel analysis. Renewable energy, 140, 341-353.

Hdom, H. A. (2019). Examining carbon dioxide emissions, fossil \& renewable electricity generation and economic growth: Evidence from a panel of South American countries. Renewable energy, 139, 186-197.

Jammazi, R., \& Aloui, C. (2015). Environment Degradation, Economic Growth and Energy Consumption Nexus: A Wavelet-Windowed Cross Correlation Approach. Physica A, 436, 110-125.

Kais, S., \& Sami, H. (2016). An Econometric Study of the Impact of Economic Growth and Energy Use on Carbon Emissions: Panel Data Evidence from Fifty-Eight Countries. Renewable and Sustainable Energy Reviews, 59, 1101-1110.

Khalid, A. M., Hamid, N. M., \&Hao-Ran, Y. U. A. N. (2017). Impact of Energy Consumption on Environmental Pollution a Case Study of Pakistan. Destech Transactions on Social Science, Education and Human Science, (icesd).

Mensah, I. A., Sun, M., Gao, C., Omari-Sasu, A. Y., Zhu, D., Ampimah, B. C., \& Quarcoo, A. (2019). Analysis on the nexus of economic growth, fossil fuel energy consumption, $\mathrm{CO} 2$ emissions and oil price in Africa based on a PMG panel ARDL approach. Journal of Cleaner Production, 228, 161-174.

Mensah, I. A., Sun, M., Gao, C., Omari-Sasu, A. Y., Zhu, D., Ampimah, B. C., \& Quarcoo, A. (2019). Analysis on the nexus of economic growth, fossil fuel energy consumption, $\mathrm{CO} 2$ emissions and oil price in Africa based on a PMG panel ARDL approach. Journal of Cleaner Production, 228, 161-174.

Muhammad, B. (2019). Energy consumption, CO2 emissions and economic growth in developed, emerging and Middle East and North Africa countries. Energy ,232-245.

Nasreen, S., Anwar, S., \& Ozturk, I. (2016). Financial Stability, Energy Consumption and Environmental Quality: Evidence from South Asian Economies. Renewable and Sustainable Energy Reviews, 67, 1105-1122.

Noor, S., \& Siddiqi, M.W., 2010. Energy consumption and economic growth in south Asian countries: a co-integrated panel analysis. Int. J. Hum. Soc. Sci. 5, 14. 
Olumuyiwa, O. S. (2012). Long run relationship between energy consumption and economic growth: Evidence from Nigeria. IOSR Journal of Humanities and Social Science, 3, 40-51.

Rehman, M. U., \& Rashid, M. (2017). Energy consumption to environmental degradation, the growth appetite in SAARC nations. Renewable Energy, 111, 284-294.

Reviews, 53, 225-234.

Safdar, N., Asif, H., \& Farooq, F. (2020). Energy Use and Human Health Nexus in Pakistan. Review of Economics and Development Studies, 6(3), 661-674.

Safdar, N., Chaudhry, I. S., \& Chaudhry, M. O. (2019). Energy Consumption, Environmental Degradation and Economic Growth in Developing Countries. Pakistan Journal of Social Sciences (PJSS), 39(2).

Saidi, K., \& Hammami, S. (2015). The Impact of CO2 Emissions and Economic Growth on Energy Consumption in 58 Countries. Energy Reports, 1, 62-70.

Sek, S. K., \& Chu, J. F. (2017). Investigating economic growth-energy consumption-environmental degradation nexus in China. International Journal of Advanced and Applied Sciences, 4(12), 21-25.

Sghari, M.B.A., \& Hammami, S. (2016). Energy, Pollution, and Economic Development in Tunisia. Energy Reports, 2, 35-39

Walde-Rufael, Y. (2010). "Bounds Test Approach to Cointegration and Causality between Nuclear Energy Consumption and Economic Growth in India." Energy Policy, Vol.38, 52-58.

Yuan, C., Liu, S., Fang, Z., \& Xie, N. (2010). The relation between Chinese economic development and energy consumption in the different periods. Energy Policy,38, 5189-5198.

Zhang, L., \& Gao, J. (2016). Exploring the Effects of International Tourism on China's Economic Growth, Energy Consumption and Environmental Pollution: Evidence from A Regional Panel Analysis. Renewable and Sustainable Energy

Zhang, Y.F., \& Gao, P. (2016). Integrating Environmental Considerations into Economic Regulation of China's Electricity Sector. Utilities Policy, 38, 62-71. 